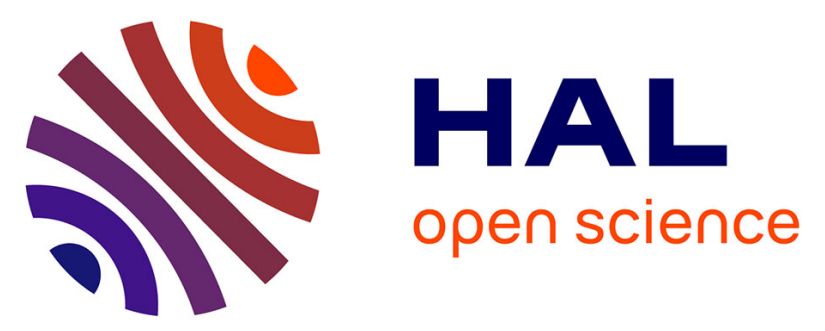

\title{
Entasis Through Hook-and-Loop Fastening in a Glycoligand with Cumulative Weak Forces Stabilizing $\mathrm{Cu}(\mathrm{I})$.
}

\author{
Ludivine Garcia, Federico Cisnetti, Natacha Gillet, Régis Guillot, Magali
} Aumont-Nicaise, Jean-Philip Piquemal, Michel Desmadril, François Lambert, Clotilde Policar

\section{To cite this version:}

Ludivine Garcia, Federico Cisnetti, Natacha Gillet, Régis Guillot, Magali Aumont-Nicaise, et al.. Entasis Through Hook-and-Loop Fastening in a Glycoligand with Cumulative Weak Forces Stabilizing $\mathrm{Cu}(\mathrm{I})$.. Journal of the American Chemical Society, 2015, 137 (3), pp.1141-1146. 10.1021/ja510259p . hal-01101575

\section{HAL Id: hal-01101575 \\ https://hal.science/hal-01101575}

Submitted on 27 Nov 2018

HAL is a multi-disciplinary open access archive for the deposit and dissemination of scientific research documents, whether they are published or not. The documents may come from teaching and research institutions in France or abroad, or from public or private research centers.
L'archive ouverte pluridisciplinaire HAL, est destinée au dépôt et à la diffusion de documents scientifiques de niveau recherche, publiés ou non, émanant des établissements d'enseignement et de recherche français ou étrangers, des laboratoires publics ou privés. 


\title{
Entasis through Hook-and-Loop Fastening in a Glycoligand with Cumulative Weak Forces Stabilizing $\mathrm{Cu}^{\prime}$
}

\author{
Ludivine Garcia, ${ }^{\dagger}$ Federico Cisnetti, ${ }^{\dagger, \perp}$ Natacha Gillet, ${ }^{\S}$ Régis Guillot, ${ }^{\dagger}$ Magali Aumont-Nicaise, ${ }^{\|}$ \\ Jean-Philip Piquemal, ${ }^{\S}$ Michel Desmadril, ${ }^{\|}$François Lambert, ${ }^{\ddagger, \#, \nabla}$ and Clotilde Policar ${ }^{*, \pm, \#, \nabla}$ \\ ${ }^{\ddagger}$ Ecole Normale Supérieure-PSL Research University, Département de Chimie, 24 rue Lhomond, F-75005 Paris, France

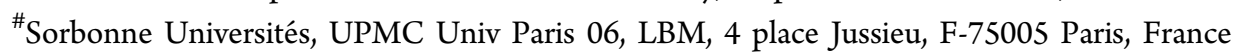 \\ ${ }^{\nabla}$ CNRS, UMR 7203 LBM, F-75005 Paris, France \\ ${ }^{\dagger}$ Institut de chimie moléculaire et des matériaux d’Orsay, UMR CNRS 8182, Bât. 420, Université Paris-Sud 11, F-91405 Orsay Cedex, \\ France \\ ${ }^{\S}$ Laboratoire de Chimie Théorique (UMR CNRS 7616), Sorbonne Universités, UPMC Univ Paris 06, Tour 12-13, 4 place Jussieu, \\ F-75252 Paris Cedex 05, France \\ "Institut de Biochimie et Biophysique Moléculaire et Cellulaire, CNRS-UMR8619, Bât. 430, Université Paris-Sud 11, F-91405 Orsay \\ Cedex, France
}

\section{Supporting Information}

ABSTRACT: The idea of a possible control of metal ion properties by constraining the coordination sphere geometry was introduced by Vallee and Williams with the concept of entasis, which is frequently postulated to be at stake in metallobiomolecules. However, the interactions controlling the geometry at metal centers remain often elusive. In this study, the coordination properties toward copper ions- $\mathrm{Cu}^{\mathrm{II}}$ or $\mathrm{Cu}^{\mathrm{I}}$ - of a geometrically constrained glycoligand centered on a sugar scaffold were compared with those of an analogous ligand built on an unconstrained alkyl chain. The sugar-centered ligand was shown to be more preorganized for $\mathrm{Cu}^{\mathrm{II}}$ coordination than its open-chain analogue, with an unusual additional stabilization of the $\mathrm{Cu}^{\mathrm{I}}$ redox state. This preference for $\mathrm{Cu}^{\mathrm{I}}$ was suggested to arise from geometric constraints favoring an optimized folding of the glycoligand minimizing steric repulsions. In other words, the $\mathrm{Cu}^{\mathrm{I}} \mathrm{d}^{10}$ species is stabilized by valence shell electron pair repulsion (VSEPR). This idea was

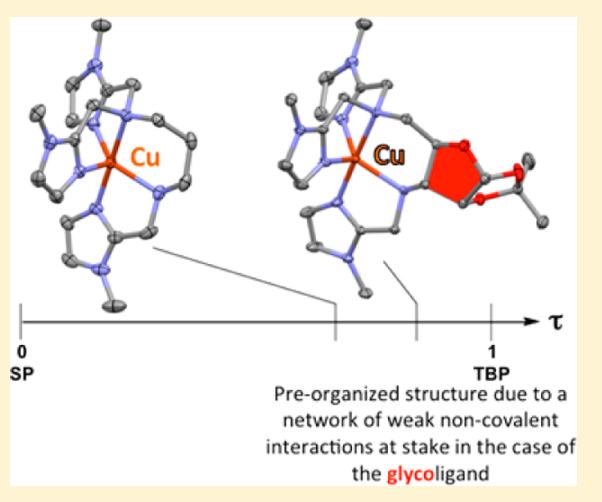
rationalized by a theoretical noncovalent interactions (NCI) analysis. The cumulative effects of weak forces were shown to create an efficient buckle as in a hook-and-loop fastener, and fine structural features within the glycoligand reduce repulsive interactions for the $\mathrm{Cu}^{\mathrm{I}}$ state. This study emphasizes that monosaccharide platforms are appropriate ligand backbones for a delicate geometric control at the metal center, with a network of weak interactions within the ligand. This structuration availing in glycoligands makes them attractive for metallic entasis.

The possible control of metal properties by the coordination geometry was an idea introduced by Vallee and Williams ${ }^{1}$ with the concept of "entatic state"2,3 and refers to proteins in which metal cations are in an unusual energized state. ${ }^{4}$ Entatic states can be achieved using structures enabling the coordination but with some constraints leading to a geometry that does not match the geometrical intrinsic requirements of the metal ion. ${ }^{2,4}$ In the case of copper(II/I) redox couple, as $\mathrm{Cu}^{\mathrm{II}}$ and $\mathrm{Cu}^{\mathrm{I}}$ cations display different geometrical requirements, the geometry can be used to control the redox potential, ${ }^{5}$ as shown in a few examples in the literature. ${ }^{6-8}$ Indeed, the control of the redox state for the $\mathrm{Cu}^{\mathrm{II} / \mathrm{I}}$ couple can be achieved by a structural constraint favoring $\mathrm{Cu}^{\mathrm{II}}$ over $\mathrm{Cu}^{\mathrm{I}}$, as explained in the following. ${ }^{5}$ $\mathrm{Cu}^{\mathrm{I}}$ is a $\mathrm{d}^{10}$ ion, and therefore, it has no structural preference based on its electronic structure. Hence, $\mathrm{Cu}^{\mathrm{I}}$ complexes often adopt 4-coordinate tetrahedral geometries, organizing Lewis bases at the farthest possible positions, as expected from the
VSEPR (valence shell electron pair repulsion) theory. $\mathrm{Cu}^{\mathrm{II}} \mathrm{d}^{9}$ ion undergoes Jahn-Teller distortion ${ }^{9}$ with a strong preference for axially distorted over perfectly octahedral structures. Then, a ligand forcing an axial distortion would favor $\mathrm{Cu}^{\mathrm{II}}$ over $\mathrm{Cu}^{\mathrm{I}}$. Since the pioneering works in the 1980 s, $^{10,11}$ geometrically constrained ligands have been described in the literature and used to control the properties of various metal ions, such as ligands bearing bulky substituents, ${ }^{12}$ in particular to control the geometry of the coordination sphere and redox potential, ${ }^{6}$ ligands with rigid spacers between Lewis bases, ${ }^{11}$ substituted macrocycles, ${ }^{13}$ capped calixarenes, ${ }^{14}$ and nonmacrocyclic ligands. ${ }^{15,16}$ An original and still scarcely used strategy is to take advantage of ligands built on a sugar central platform that acts as a constrained central platform to control the 
physicochemical properties of the derived complexes. ${ }^{17-21}$ We developed glycoligands as a family of monosaccharides with appended chelating units, which could embed different ions with control of the chelation site $22-32$ and of physicochemical properties such as magnetic properties, ${ }^{23}$ stereochemistry, ${ }^{24,31}$ and binding constant. ${ }^{32}$ In the present article, the coordination properties of a ligand centered on a ribo scaffold (L) are compared to those of an analogous ligand built on an open unconstrained alkyl chain $\left(\mathrm{L}^{\prime}\right)$. Interestingly, a preorganization of the ribo-centered ligand (L) for $\mathrm{Cu}^{\mathrm{II}}$ coordination with a higher stabilization of the $\mathrm{Cu}^{\mathrm{I}}$ redox state in the case of $\mathrm{L}$ was evidenced experimentally. This has been rationalized by a theoretical noncovalent interactions (NCI) analysis. ${ }^{33,34}$ This approach, focusing at the weak VSEPR interactions in an extended network involving the ligand at the immediate metal neighborhood, showed a clear loss in repulsive interactions in the $\mathrm{Cu}^{\mathrm{I}}$ state both in the glycocomplex and in its analogue, with some significant additional stabilization in the case of the ribobased system. Possible fine tuning of redox potential by noncovalent interactions in $\mathrm{Cu}$-proteins has arisen some interest lately, ${ }^{35,36}$ and the study reported here shows that this can be achieved in small complexes. Interestingly, it was shown that the cumulative effects of several weak interactions, identified by the NCI method, can be a source of efficient stabilization for $\mathrm{Cu}$, as in a hook-and-loop fastener.

\section{RESULTS AND DISCUSSION}

To study the influence of the constraints of the sugar platform on the properties of $\mathrm{Cu}^{\mathrm{II}}$ complexes, we synthesized a glycoligand (L) based on a ribo-furano scaffold with an isopropylidene ketal that acts as a conformational lock and its unconstrained analogue $\left(\mathrm{L}^{\prime}\right)$ based on an open alkyl chain (see Figure 1, Material and Methods, and Supporting Information for synthesis).

The structure of the $\mathrm{Cu}^{\mathrm{II}}$ complexes was solved by X-ray crystallography in the solid state. As shown in Figure 1 (see also Supporting Information), the structure of $[\mathrm{Cu}(\mathrm{L})]^{2+}$ is closer to the ideal trigonal bipyramid (TBP) than that of $\left[\mathrm{Cu}\left(\mathrm{L}^{\prime}\right)\right]^{2+}$, which is distorted toward the square pyramid (SP) $(\tau=0.84$ and 0.67 , respectively, $\tau=1$ being for an ideal TBP and $\tau=0$ for an ideal SP). ${ }^{37}$ Overall, the spectroscopic properties in solution, both in X-band EPR as well as UV-vis, are consistent with the X-ray structures (see Supporting Information, Figures S3 and S4). Interestingly, the redox potential of the glycocomplex couple was significantly higher than that for the acyclic analogue $\left(E_{\text {glyco }}^{\circ}=-39 \mathrm{mV} / \mathrm{NHE}, E_{\text {acy }}^{\circ}=-121 \mathrm{mV} /\right.$ NHE, $\Delta E_{\text {glyco-acy }}=82 \mathrm{mV}$ ) (see Supporting Information, Figure S5).

Complexation of $\mathrm{Cu}^{\mathrm{II}}$ by $\mathrm{L}$ and $\mathrm{L}^{\prime}$ was studied in $\mathrm{EtOH}$ by isothermal titration calorimetry (ITC) to determine the various thermodynamic parameters, including the association constant $(K)$, the binding enthalpy $(\Delta H)$, and the entropy $(\Delta S)$ at 298 K. Figure S6, Supporting Information, depicts the series of exothermic heat profiles for the titration of $\mathrm{L}$ and $\mathrm{L}^{\prime}$ with $\mathrm{Cu}^{\mathrm{II}}$ ion, and the parameters from the simulation (see Material and Methods and Supporting Information) are reported in Table 1.

The binding enthalpy $\Delta H$ reflects classical steric termssuch as van der Waals - as well as electrostatic interactions and hydrogen bonding but also angular and torsional strains and electronic contributions. The entropy $\Delta S$ is associated with the reorganization of the ligand upon complexation. ${ }^{38-40}$ For the reaction $\left[\mathrm{Cu}^{\mathrm{II}}\left(\mathrm{OH}_{2}\right)_{n}\right]^{2+}+\mathrm{Lgd}_{\mathrm{aq}}=[\mathrm{Cu}(\mathrm{Lgd})]^{2+}+n^{\prime} \mathrm{H}_{2} \mathrm{O}$ (Ldg = ligand, $n^{\prime}$ can be greater than $n$ if the ligand was

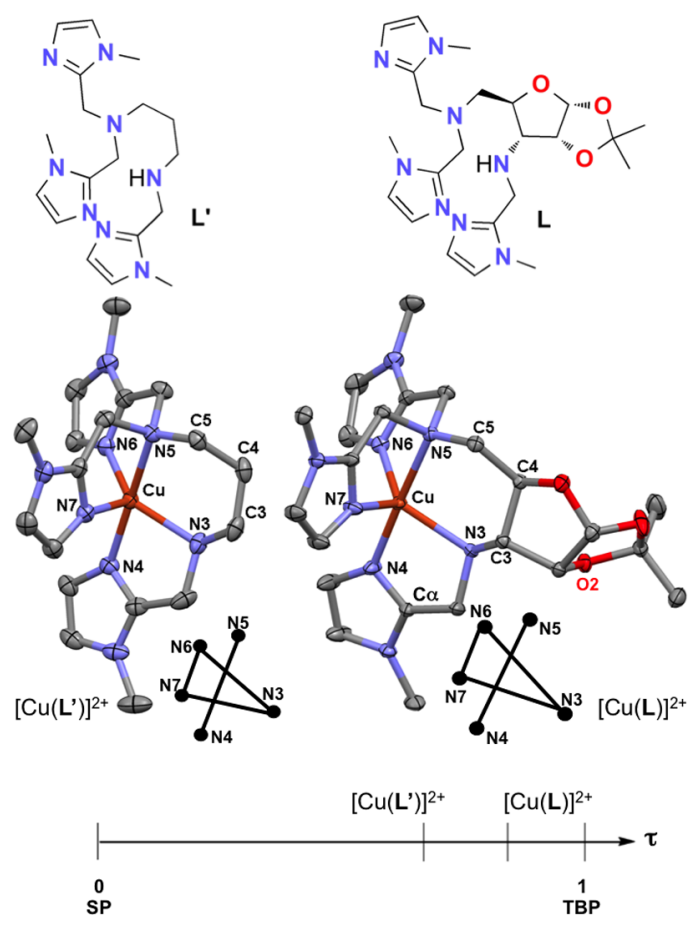

Figure 1. Structures of $\mathrm{L}$ and $\mathrm{L}^{\prime}$. Representation of the $[\mathrm{Cu}(\mathrm{L})]^{2+}$ unit in the solid state structure of $[\mathrm{Cu}(\mathrm{L})]\left(\mathrm{PF}_{6}\right)_{2}$ and of the $\left[\mathrm{Cu}\left(\mathrm{L}^{\prime}\right)\right]^{2+}$ unit in the solid state structure of $\left[\mathrm{Cu}\left(\mathrm{L}^{\prime}\right)\right]_{2}\left(\mathrm{NO}_{3}\right)\left(\mathrm{PF}_{6}\right)_{3} \cdot 2 \mathrm{CH}_{3} \mathrm{OH}$, showing anisotropic vibration ellipsoids (probability 50\%). (Bottom) $\tau$ axis showing the distortion of the two structures with regard to TBP and SP.

solvated), solvation effects, both at the metal ion and at the ligand level, are also important enthalpic and entropic factors. The release of water molecule(s) to solvent upon binding of a polydentate ligand induces an increase in disorder and hence a favorable entropic contribution. ${ }^{41}$ In the present study, the two ligands offer a similar $3 \mathrm{~N}_{\mathrm{im}}-2 \mathrm{~N}_{\mathrm{amine}}$ coordination sphere. Despite the difference in steric constraints at the central scaffold and in the ligands folding, the Lewis bases are likely to be similarly exposed to the solvent, with similar solvation and similar changes in solvation upon binding the $\mathrm{Cu}^{\mathrm{II}}$ ion. Hence, by comparing the two ligands, alkyl $\left(\mathrm{L}^{\prime}\right)$ and glyco centered (L), the solvation contribution compensate for each other, and they are therefore not considered in the following discussion.

The binding constant of $\mathrm{Cu}$ iI to $\mathrm{L}$ was found to be 20 times higher than that for $\mathrm{L}^{\prime}$, which was paradoxically associated with a less negative binding enthalpy (Table 1). This suggests that the constraints from the ribo platform prevent optimization of the $\mathrm{Cu}-\mathrm{N}$ distances. This is particularly true in the case of $\mathrm{Cu}-$ $\mathrm{N}_{\text {alkyl }}(\mathrm{N} 3$ and N5) included in the metallacycle $(\mathrm{Cu}-\mathrm{N} 3-\mathrm{C} 3-$ C4-C5-N5), which is fused with the furanoid cycle in the case of $\mathrm{L}$ (see Table S2, Supporting Information). In addition, the observation that $\left|\Delta H\left(\left[\mathrm{Cu}\left(\mathrm{L}^{\prime}\right)\right]^{2+}\right)\right|>\left|\Delta H\left([\mathrm{Cu}(\mathrm{L})]^{2+}\right)\right|$ indicates a higher covalency for the $\mathrm{Cu}-\mathrm{N}$ bonds in $\left[\mathrm{Cu}\left(\mathrm{L}^{\prime}\right)\right]^{2+}$, which is also suggested by the comparison of the molar extinction coefficients in UV-vis spectra, the higher value for $\left[\mathrm{Cu}\left(\mathrm{L}^{\prime}\right)^{2+}\right]$ being indicative of a higher covalency (see Supporting Information). The higher stability of the complex $[\mathrm{Cu}(\mathrm{L})]^{2+}$ is clearly of an entropic origin. Indeed, the entropy loss observed in the case of $[\mathrm{Cu}(\mathrm{L})]^{2+}$ is so small that this contribution overcompensates the enthalpy and leads to an increased $K$ value in comparison with $\left[\mathrm{Cu}\left(\mathrm{L}^{\prime}\right)\right]^{2+}$. This smaller entropy loss is the consequence of weaker reorganization of the 
Table 1. Thermodynamic Parameters of the Association Constant and Computed Values of $\Delta G, \Delta H$, and $\Delta S^{a}$

$\begin{array}{clccrr}\mathrm{L} / \mathrm{L}^{\prime} & & K_{\mathrm{Cu}(\mathrm{II}) \mathrm{Ligand}} & \Delta G^{b} & \Delta H^{b} & -T \Delta S^{b} \\ \mathrm{~L} & \exp & (2.9 \pm 0.05) \times 10^{7} & -10.20 & -12.78 \pm 0.05 & 2.59 \\ & \text { calcd } & & -11.98 & -13.69 & 1.71 \\ \mathrm{~L}^{\prime} & \exp & (1.5 \pm 0.2) \times 10^{6} & -8.47 & -20.77 \pm 0.16 & 12.30 \\ & \text { calcd } & & -9.02 & -21.14 & 12.13\end{array}$

${ }^{a}$ Exp: Thermodynamic parameters of the association constant $\left[\mathrm{Cu}^{\mathrm{II}}\left(\mathrm{OH}_{2}\right)_{n}\right]^{2+}+\operatorname{Lgd}_{\mathrm{aq}}=\left[\mathrm{Cu}^{\mathrm{II}}(\mathrm{Lgd})\right]^{2+}+n^{\prime} \mathrm{H}_{2} \mathrm{O}\left(\mathrm{Lgd}=\mathrm{L}\right.$ or $\left.\mathrm{L}^{\prime}\right)$ Determined by ITC at $298 \mathrm{~K}$ in EtOH (see Supporting Information). Calcd: computed values of $\Delta G, \Delta H$, and $\Delta S$ using Gaussian in the gas phase $\left(\mathrm{Cu}^{2+}+\mathrm{Lgd}=\right.$ $[\mathrm{Cu}(\mathrm{Lgd})]^{2+}$ (see Supporting Information)). ${ }^{b} \Delta G, \Delta H$, and $T \Delta S$ in $\mathrm{kcal} \mathrm{mol}^{-1}$

ligand structure upon coordination ${ }^{4}$ in the case of $\mathrm{L}$ than in the case of $L^{\prime}$, suggesting a higher preorganization of the glycoligand $\mathrm{L}$ for the coordination of $\mathrm{Cu}{ }^{\mathrm{II}}$. Preorganization is a concept that usually avails for macrocyclic ligands and cryptates that refers to the entropic loss associated with the freezing of the ligand in a conformation close to that encountered in the complex itself. ${ }^{15,42}$ Preorganization includes the overcoming of repulsive forces between polar groups coming toward each other in the complexation process: if they are already close in the ligand, this unfavorable interaction preexists in the ligand itself and is not working against complexation. ${ }^{42}$ The chelating part in both $\mathrm{L}$ and $\mathrm{L}^{\prime}$ is an open-chain ligand with constraints induced by the glyco scaffold in L. This study is fully consistent with the idea according to which the concept of preorganization ${ }^{42}$ can be an important factor governing the stabilities of the complexes derived from open-chain ligands.

To confirm this suggested preorganization of the glycoligand $\mathrm{L}$ for $\mathrm{Cu}^{\mathrm{II}}$ coordination, the structure of the sugar ring in the metal-free ligand in solution was compared with its structure in the coordinated ligand in the solid state. To do so, the coupling constants ${ }^{3} J_{\text {calcd, calculated using the Haasnoot-Altona }}$ equation $^{43}$ and $\mathrm{H}-\mathrm{C}-\mathrm{C}-\mathrm{H}$ torsion angles in the sugar from the solid state structure of $[\mathrm{Cu}(\mathrm{L})]\left(\mathrm{PF}_{6}\right)_{2}$ were compared with the experimental coupling constant ${ }^{3} J_{\exp }$ obtained by ${ }^{1} \mathrm{H}$ NMR of $\mathrm{L}$ in solution (see details of the Haasnoot and Altona analysis in the Supporting Information). Interestingly, a good match was obtained indicating that the structure of ribo platform is unchanged upon complexation. This result clearly supports the preorganization of $\mathrm{L}$ for $\mathrm{Cu}^{\mathrm{II}}$ coordination.

Rorabacher and co-workers have shown in the case of a series of tripodal ligands containing $\mathrm{N}$ and $\mathrm{S}$ donor atoms that an increase in $\mathrm{Cu}^{\mathrm{II} / \mathrm{I}}$ redox potentials was associated with the relative destabilization of the $\mathrm{Cu}^{\mathrm{II}}$ complexes rather than with stabilization of the $\mathrm{Cu}^{\mathrm{I}}$ species. ${ }^{5}$ In the present case, $\left[\mathrm{Cu}^{\mathrm{II}}(\mathrm{L})\right]^{2+}$ was shown to be 20 times more stable than $\left[\mathrm{Cu}^{\mathrm{II}}\left(\mathrm{L}^{\prime}\right)\right]^{2+}$ (see above). The higher redox potential observed for the $\mathrm{Cu}^{\mathrm{II} / \mathrm{I}}$ complexes derived from $\mathrm{L}$ can then only be explained by a much higher stability of the $\mathrm{Cu}^{\mathrm{I}}$ complex derived from $\mathrm{L}$ in comparison with $\mathrm{L}^{\prime}$. Indeed, the potential values of the $\mathrm{Cu}^{\mathrm{II} / \mathrm{I}}$ redox couples are dependent on the stability constants of both $\mathrm{Cu}$ and $\mathrm{Cu}^{\mathrm{II}}$ complexes according to

$$
\begin{aligned}
E_{\text {glyco or acy }}^{\circ}= & {E^{\circ}}_{\mathrm{Cu}(\mathrm{II}) / \mathrm{Cu}(\mathrm{I})}-(2.303 R T / n F) \\
& \log \left(K_{\mathrm{Cu}(\mathrm{II})(\mathrm{Lgd})} / K_{\mathrm{Cu}(\mathrm{I})(\mathrm{Lgd})}\right)
\end{aligned}
$$

where $E^{\mathrm{o}} \mathrm{Cu}(\mathrm{II}) / \mathrm{Cu}(\mathrm{I})$ is the standard potential of the $\mathrm{Cu}^{\mathrm{II} / \mathrm{I}}$ redox couple in ethanol $\left(E_{\text {glyco }}^{\circ}\right.$ for $\mathrm{Lgd}=\mathrm{L}$ and $E_{\text {acy }}^{\circ}$ for $\mathrm{Lgd}=\mathrm{L}^{\prime}$ )

Generally speaking, the folding of a ligand to chelate a metal ion induces unfavorable steric interactions. ${ }^{4,39,42} \mathrm{As} \mathrm{Cu}(\mathrm{I}) \mathrm{d}^{10}$ has no structural preference, its complexes will adopt a geometry that minimizes these steric repulsions. Their geometry should therefore be dictated by the VSEPR theory: for a pentadentate ligand, the optimal spatial distribution of the five donor atoms should be TBP, which occupies the whole $3 \mathrm{D}$ space, and not SP, which occupies only half-space. The ligand $\mathrm{L}$ in $[\mathrm{Cu}(\mathrm{L})]^{2+}$ was shown to offer a preorganized coordination sphere closer to TBP than to SP (see Figure 1, bottom). Hence, the higher stabilization of $\mathrm{Cu}^{\mathrm{I}}$ by $\mathrm{L}$ could be understood as a VSEPR-controlled stabilization.

To support this suggestion of a VSEPR-controlled stability for the $\mathrm{Cu}^{\mathrm{I}}$ complex with $\mathrm{L}$ we performed a gas-phase quantum chemical study at the B3LYP/6-31G++** level ${ }^{44-46}$ of the noncovalent interactions (NCI) at work within the $\mathrm{Cu}^{\mathrm{II}}$ and $\mathrm{Cu}^{\mathrm{I}}$ complexes of both $\mathrm{L}$ and $\mathrm{L}^{\prime}$ ligands. To do so, we used the NCI plot program ${ }^{34}$ recently introduced by one of us which allows one to perform a NCI analysis (noncovalent interaction). ${ }^{33,34}$ Analysis of the electron density enables the visualization and quantification of local weak interactions. To the best of our knowledge, this method has still seldom been used for transition metal complexes and this is its first application to investigate the influence of the metal redox state. Details about the NCI method are provided in the Supporting Information (see also refs 33, 47, and 48). This analysis provides $3 \mathrm{D}$ representations of the interaction surfaces meant to locate the repulsive and attractive troughs within the atomic structure. In these representations, the nature of the interaction is color coded: red for repulsive, green for weakly attractive or repulsive, and blue for attractive interactions.

The NCI approach is a powerful tool to study weak interactions. ${ }^{33,34}$ We compared the interaction network within $[\mathrm{Cu}(\mathrm{L})]^{2+},[\mathrm{Cu}(\mathrm{L})]^{+},\left[\mathrm{Cu}\left(\mathrm{L}^{\prime}\right)\right]^{2+}$, and $\left[\mathrm{Cu}\left(\mathrm{L}^{\prime}\right)\right]^{+}$structures. Two kinds of domains were considered to understand the stability of transition metal complexes: (a) the metal subvalence core corresponding to the partially covalent coordination bonding and (b) the ligand interaction network including destabilizing interactions due to steric packing. ${ }^{47,48}$

For $\mathrm{Cu}^{\mathrm{II}}$ complexes, the NCI analyses were performed using the crystallographic structures. Overall, the optimized coordination sphere geometries are very close for $\mathrm{L}$ and $\mathrm{L}^{\prime}$ and to the experimental values (see Table S6, Supporting Information). Table 1 shows thermodynamic parameters computed using the Gaussian software on optimized structures based on crystallographic data at the same level of computation used for the NCI computation (see Supporting Information). A good qualitative agreement between experimental and computed values was obtained. The interaction network shown in the NCI-3D plot in Figure 2 involves stabilizing interactions (in blue) that clearly correspond to ligand- $\mathrm{Cu}$ bonds or subvalence core. Within the ligand interaction network of both $\mathrm{Cu}^{\mathrm{II}}$ complexes two features are noteworthy.

(a) The ligand interaction network leads to a weak overall stabilization because the involved interactions are dual, with an attractive domain (blue to green) that is 

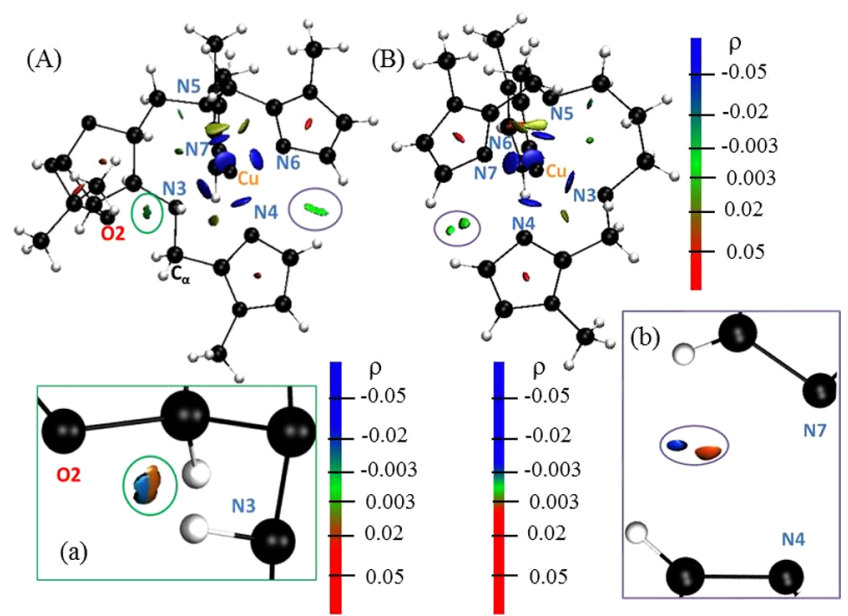

Figure 2. NCI-3D of $[\mathrm{Cu}(\mathrm{L})]^{2+}(\mathrm{A})$ and $\left[\mathrm{Cu}\left(\mathrm{L}^{\prime}\right)\right]^{2+}$ (B): (blue domains) Strong attractive noncovalent interactions, (green) weak interactions, and (red) repulsive interactions. $\mathrm{O}_{2}-\mathrm{H}_{\mathrm{N} 3}$ interaction is highlighted by the green circle and enlarged in a. (b) Dual interactions between imidazole rings. Note that the color scale depends on the value of the electronic density chosen for the representation of the interactions. It can be modulated to highlight the red/repulsive or blue/attractive character of usually green/weak interactions. In this figure, the electronic density scale is different for the global complexes and for each insert. The corresponding color scale is given next to each picture. Figures are available as movies in the Supporting Information, see movies $1\left([\mathrm{Cu}(\mathrm{L})]^{2+}\right)$ and $2\left(\left[\mathrm{Cu}\left(\mathrm{L}^{\prime}\right)\right]^{2+}\right)$.

compensated by a repulsive contribution (red) from steric effects (see Figure 2). This indicates overpacking for both $[\mathrm{Cu}(\mathrm{L})]^{2+}$ and $\left[\mathrm{Cu}\left(\mathrm{L}^{\prime}\right)\right]^{2+}$. This is the case, for instance, for interaction between imidazole rings (see Figure 2 insert (b)).

(b) Overall, there is a larger number of these interactions for the glycoligand $\mathrm{L}$ than for the acyclic ligand $\mathrm{L}^{\prime}$. For instance, an additional $\mathrm{H}$ bond is clearly observed in $[\mathrm{Cu}(\mathrm{L})]^{2+}$ between $\mathrm{O}_{2}$ and $\mathrm{H}_{\mathrm{N} 3}$ as depicted in Figure 2a, which appeared dual with both attractive and repulsive features. Because of this compensation, the $\mathrm{H}$ bond is only weakly attractive.

Clearly, $[\mathrm{Cu}(\mathrm{L})]^{2+}$ exhibits an extended network of weak interactions ranging from $\mathrm{H}$-bond to van der Waals interactions that is much richer than in $\left[\mathrm{Cu}\left(\mathrm{L}^{\prime}\right)\right]^{2+}$. This is an important main difference. The present analysis shows that the overall stabilization provided by this network is weak due to the compensation of attractive interactions and repulsive interactions, with the repulsive part due to steric crowding.

For the analysis of the $\mathrm{Cu}^{\mathrm{I}}$ complexes, the structures complexes were optimized at the B3LYP/6-31G++** level. $\mathrm{The} \mathrm{Cu}^{\mathrm{II}} \rightarrow \mathrm{Cu}^{\mathrm{I}}$ reduction globally relaxes the coordination spheres with an increase in $\mathrm{N}-\mathrm{Cu}$ with both ligands (see Table S6, Supporting Information). The geometry is TBP with a strong axial distortion, leading to an environment close to trigonal, with a global loosening of the steric crowding and repulsions within the ligand interaction network (see Figure 3 and movies $3\left([\mathrm{Cu}(\mathrm{L})]^{+}\right)$and $4\left(\left[\mathrm{Cu}\left(\mathrm{L}^{\prime}\right)\right]^{+}\right)$, Supporting Information).

In other words, the reduction to $\mathrm{Cu}^{\mathrm{I}}$ induces a dilatation of the subvalence core, which was expected from the ionic radii of $\mathrm{Cu}^{\mathrm{I}}$ and $\mathrm{Cu}^{\mathrm{II}}{ }^{49}$ This dilatation leads to a weakening of the repulsive steric contributions, and therefore, the attractive contributions of the ligand interaction network prevail in the

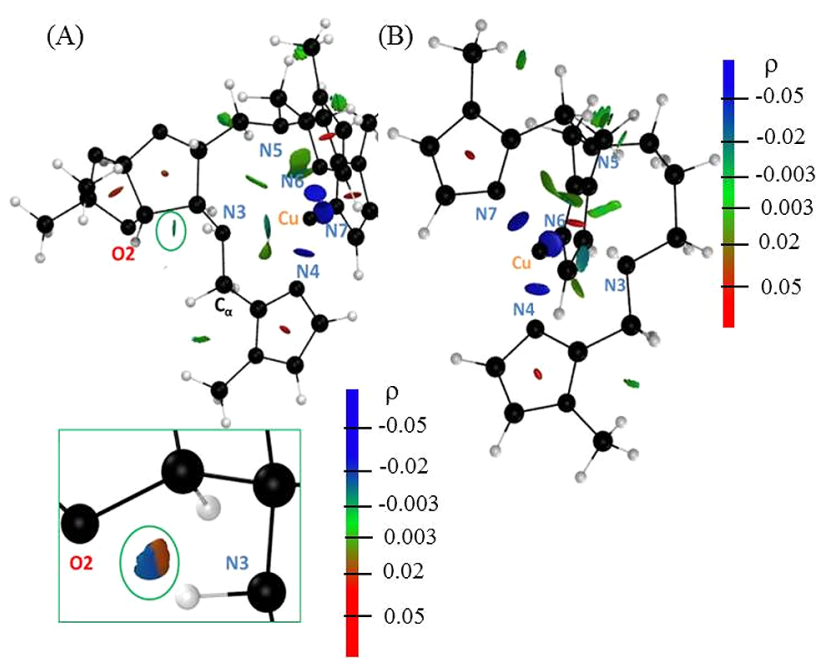

Figure 3. NCI-3D of $[\mathrm{Cu}(\mathrm{L})]^{+}(\mathrm{A})$ and $\left[\mathrm{Cu}\left(\mathrm{L}^{\prime}\right)\right]^{+}(\mathrm{B})$ : (blue domains) strong attractive noncovalent interactions, (green domains) weak interactions, and (red domains) repulsive interactions (see also movies 1 and 3, Supporting Information). The electronic density scale is different for the global complexes and for the inset of the $\mathrm{O}_{2}-\mathrm{H}_{\mathrm{N} 3}$ interaction. The corresponding color scale is given next to each picture.

$\mathrm{Cu}^{\mathrm{I}}$ structures. As this attractive network is richer in the case of the $\mathrm{L}$ complex, the stabilizing effect upon reduction is stronger.

Two specific examples can be given to illustrate this richer network leading to an enhanced stabilization of $[\mathrm{Cu}(\mathrm{L})]^{+}$.

(a) The steric repulsion between imidazole rings and generally in the $\mathrm{Cu}$-ion surroundings are reduced in the $\mathrm{Cu}^{\mathrm{I}}$ complexes: as seen on the NCI-3D representations, the number of red/repulsive troughs between imidazole rings is smaller in the case of the $\mathrm{Cu}^{\mathrm{I}}$ with a higher number of green/attractive troughs than in the case of the $\mathrm{Cu}^{\mathrm{II}}$ compounds (compare Figure 3 with Figure 2, see also figures in the Supporting Information and movies).

(b) The hydrogen bond between $\mathrm{O}_{2}$ and $\mathrm{H}_{\mathrm{N} 3}$ strengthens with a weaker repulsive contribution than in the case of the $\mathrm{Cu}^{\mathrm{II}}$ structure and an additional attractive interaction with $\mathrm{H}_{\mathrm{Cl}}$ with a smaller $\mathrm{O}_{2}-\mathrm{H}_{\mathrm{Cl}}$ distance in the $\mathrm{Cu}^{\mathrm{I}}$ complex (see Table S6, Supporting Information).

The NCI analyses provide a fine understanding of the effect of the ribo platform. Most of the interactions are similar for the $\mathrm{L}$ and $\mathrm{L}^{\prime}$ complexes, but importantly, the ribo platform induces additional weak interactions. The relaxation of the coordination sphere upon copper reduction decreases the steric congestion for both $\mathrm{L}$ and $\mathrm{L}^{\prime}$. The NCI analysis reveals that, in the case of $\mathrm{L}$, the overall interaction network, because it involves a higher number of weak interactions than in $L^{\prime}$, becomes significantly more attractive in the $\mathrm{Cu}^{\mathrm{I}}$ complex: as in a hook-and-loop fastener, the combination of several weak attractive interactions leads to a significantly higher stability of $[\mathrm{Cu}(\mathrm{L})]^{+}$. The present $\mathrm{NCI}$ analysis focused at the VSPER interactions network can be directly linked to both experiment and computed thermodynamic values (see Table 1). The extended network identified for $\mathrm{L}$ induces a rigidity higher for $\mathrm{L}$ than for $\mathrm{L}^{\prime}$, which organizes $\mathrm{L}$ in a conformation suitable for coordination. For the ribo scaffold, a large part of the loss in entropy associated with the reduction of conformational space upon complexation preexists in uncomplexed $\mathrm{L}$. The same trends are observed with 
both oxidation states. For $\mathrm{Cu}^{\mathrm{I}}$, free energies are larger in values, giving also a preference for $\mathrm{L}\left(\Delta \Delta G\left(\mathrm{Cu}^{\mathrm{I} v s C \mathrm{vu}^{\mathrm{II}}}\right)=-3.1 \mathrm{kcal}\right.$ $\mathrm{mol}^{-1}$ for L, see Supporting Information). Differences between $\mathrm{L}$ and $\mathrm{L}^{\prime}$ complexes are mainly due to $\Delta S$ values, which are found to be also similar to $\mathrm{Cu}^{\mathrm{II}}$ with a value lower by $11.2 \mathrm{kcal}$ $\mathrm{mol}^{-1}$ for $\mathrm{L}$. Thus, there is an additional cohesion within $\mathrm{L}$, which is similar in its $\mathrm{Cu}^{\mathrm{II}}$ and $\mathrm{Cu}^{\mathrm{I}}$ complexes, associated with multiple interactions that have been unraveled by NCI. Overall stabilities of the networks were verified by performing NCI on limited $\mathrm{ab}$ initio Born-Oppenheimer molecular dynamics trajectories (225 fs simulation at the same level). ${ }^{50}$ These analyses were performed in the gas phase, but similar interaction patterns have been observed in the presence of a continuum solvation model (PCM, see Supporting Information). ${ }^{44}$

These computational results from the NCI analysis highlight the role of the ribo platform in the extended network bridging the metal density to the ligand and provide an extended view of the VSEPR argument based on the experimental observations.

\section{CONCLUSION}

The coordination properties of a glycoligand based on a ribo platform (L) and its open-chain analogue $\left(\mathrm{L}^{\prime}\right)$ have been investigated by several physicochemical techniques, including UV-vis and EPR spectroscopies, ITC, and cyclic voltammetry. The preorganization of the glycoligand $\mathrm{L}$ for coordination of $\mathrm{Cu}^{\mathrm{II}}$ has been evidenced by ITC and by comparison of structural data in the solid state (X-ray structure) and in solution (NMR). The comparison of the electrochemical properties of the two couples $[\mathrm{Cu}(\mathrm{L})]^{2+} /[\mathrm{Cu}(\mathrm{L})]^{+}$and $\left[\mathrm{Cu}\left(\mathrm{L}^{\prime}\right)\right]^{2+} /\left[\mathrm{Cu}\left(\mathrm{L}^{\prime}\right)\right]^{+}$has suggested that $\mathrm{L}$ has a preference for $\mathrm{Cu}^{\mathrm{I}}$ over $\mathrm{Cu}^{\mathrm{II}}$ compared with the acyclic ligand. This preference for $\mathrm{Cu}^{\mathrm{I}}$ can be rationalized by the geometric constraints imposed by the sugar, which favor an optimized arrangement of $\mathrm{L}$ folding in space, minimizing steric repulsions. In other words, the stability of the two $\mathrm{Cu}^{\mathrm{I}}$ complexes is controlled by VSEPR.

This proposition was questioned using the NCI method. This approach takes into account an extended VSEPR network, including both the close-by ligands and the metal domain. A network of weak interactions is at stake and must be considered for an adequate description of the metal complexes stabilization. The steric constraints imposing an extended coordination sphere in the glycoligand are clearly associated with the stabilization of the $\mathrm{Cu}^{\mathrm{I}}$ glycocomplex. The net cumulative stabilization effect is induced by the weakening of the repulsive interactions due to the dilatation of the coordination core. Interestingly, this weak interaction network is shown to be the source of an efficient stabilization, as in a hook-and-loop fastener where the cumulative effects of weak forces create an efficient buckle. This study is thus an original and unprecedented demonstration of a VSEPR stabilization of $\mathrm{Cu}^{\mathrm{I}}$ complexes through efficient relaxation of repulsive interactions. Clearly, fine structural features in the glycoligand contribute to the stabilization of the $\mathrm{Cu}^{\mathrm{II}}$ complex and also, to a larger extent, of the $\mathrm{Cu}^{\mathrm{I}}$ complex. This study thus emphasizes that monosaccharide platforms are appropriate ligand backbones for a delicate geometric control of the properties of the complexes with a network of weak interactions within the ligand mimicking in a close shell interaction at stake in biomolecules structuration. This structuration availing in glycoligand makes them attractive for metallic entasis.

\section{MATERIAL AND METHODS}

Ligands Synthesis. The ligands were synthesized by classical reductive amination. Treatment of 3,5-diaminodideoxy-1,2-O-isopropylidene- $\alpha$-D-ribo-furanose, synthesized as previously described ${ }^{51}$ with 3 equiv of 2 -( $\mathrm{N}$-methyl)-imidazolyl-carboxaldehyde using $\mathrm{NaBH}$ $(\mathrm{OAc})_{3}$ as a reductive agent in 1,2-dichloroethane, gave selectively $\mathrm{L}$ in $41 \%$ yield. Selectivity for the $5 N, 5 N, 3 N$-trisubstitution can be rationalized by the steric hindrance from the cyclic isopropylidene acetal preventing disubstitution of N3 (see numbering in Figure 1). Similar synthesis from $N, N^{\prime}$-bis ((1-methylimidazol-2-yl)methyl)-1,3diaminopropane provided $\mathrm{L}^{\prime}$ (yield $57 \%$ ). Details and full characterization are provided in the Supporting Information.

Complexes. The complexes were obtained by addition of an equimolar amount of $\mathrm{Cu}\left(\mathrm{NO}_{3}\right)_{2} \cdot 3 \mathrm{H}_{2} \mathrm{O}$ in EtOH. Addition of $\mathrm{NH}_{4} \mathrm{PF}_{6}$ ( 2.5 equiv) resulted in an immediate precipitation. The precipitate was redissolved using acetone, and crystals suitable for X-ray diffraction were grown by slow evaporation. Details of the complexes characterization, crystal data, data collection, and refinement are given in the Supporting Information.

Computations were performed using the Gaussian package ${ }^{44}$ The B3LYP functional ${ }^{45,46}$ was used along with the $6-31++\mathrm{G}^{* *}$ basis set $^{52}$ for all computations.

Experimental Details. Materials and methods including chemicals, synthesis of the ligands, crystal data of the complexes, physicochemical characterization of the complexes, and NCI analyses can be found in the Supporting Information.

\section{ASSOCIATED CONTENT}

\section{Supporting Information}

Synthesis of the ligands and preparation of the complexes, crystal data of the complexes, physico-chemical characterization of the complexes (UV-vis spectra, cyclovoltammograms, thermograms, Haasnoot and Altona's analyses, computations, and NCI analyses. This material is available free of charge via the Internet at http://pubs.acs.org.

\section{AUTHOR INFORMATION}

\section{Corresponding Author}

clotilde.policar@ens.fr

\section{Present Address}

${ }^{\perp}$ F.C.: Clermont Université, Université Blaise Pascal ICCF, UMR CNRS 6296 Aubière, France.

\section{Author Contributions}

All authors have given approval to the final version of the manuscript.

\section{Notes}

The authors declare no competing financial interest.

\section{ACKNOWLEDGMENTS}

L.G. and C.P. thank the Ecole Normale Supérieure de Cachan for a Ph.D. fellowship for L.G. The French ministry of research is gratefully acknowledged for financial support (ACIJCJC4044).

\section{REFERENCES}

(1) Vallee, B. L.; Williams, R. J. P. Proc. Natl. Acad. Sci. U.S.A. 1968, 59, 498.

(2) Comba, P. Coord. Chem. Rev. 2000, 200, 217

(3) Williams, R. J. P. Eur. J. Biochem. 1995, 234, 363.

(4) Comba, P.; Schiek, W. Coord. Chem. Rev. 2003, 238, 21.

(5) Rorabacher, D. B. Chem. Rev. 2004, 104, 651.

(6) Muller, E.; Piguet, C.; Bernardinelli, G.; Williams, A. F. Inorg. Chem. 1988, 27, 849 . 
(7) Ambundo, E. A.; Deydier, M. V.; Grall, A. J.; Aguera-Vega, N.; Dressel, L. T.; Cooper, T. H.; Heeg, M. J.; Ochrymowycz, L. A.; Rorabacher, D. B. Inorg. Chem. 1999, 38, 4233.

(8) Taylor, M. K.; Stevenson, D. E.; Berlouis, L. E. A.; Kennedy, A. R.; Reglinski, J. J. Inorg. Biochem. 2006, 100, 250.

(9) Veidis, M. V.; Schreibe, Gh; Gough, T. E.; Palenik, G. J. J. Am. Chem. Soc. 1969, 91, 1859.

(10) Hancock, R. D.; Martell, A. E. Chem. Rev. 1989, 89, 1875.

(11) Knapp, S.; Keenan, T. P.; Zhang, X.; Fikar, R.; Potenza, J. A.; Schugar, H. J. J. Am. Chem. Soc. 1987, 109, 1882.

(12) Jiang, X.; Bollinger, J. C.; Lee, D. J. Am. Chem. Soc. 2005, 127, 15678

(13) Hubin, T. J. Coord. Chem. Rev. 2003, 241, 27.

(14) Zeng, X.; Coquiere, D.; Alenda, A.; Garrier, E.; Prange, T.; Li, Y.; Reinaud, O.; Jabin, I. Chem.-Eur. J. 2006, 12, 6393.

(15) Hancock, R. D.; Melton, D. L.; Harrington, J. M.; McDonald, F. C.; Gephart, R. T.; Boone, L. L.; Jones, S. B.; Dean, N. E.; Whitehead, J. R.; Cockrell, G. M. Coord. Chem. Rev. 2007, 251, 1678.

(16) Durot, S.; Policar, C.; Cisnetti, F.; Lambert, F.; Renault, J. P.; Pelosi, G.; Blain, G.; Korri-Youssoufi, H.; Mahy, J. P. Eur. J. Inorg. Chem. 2005, 3513.

(17) Dhungana, S.; Harrington, J. M.; Geblhardt, P.; Mollmann, U.; Crumbliss, A. L. Inorg. Chem. 2007, 46, 8362.

(18) Dieguez, M.; Pamies, O.; Ruiz, A.; Diaz, Y.; Castillon, S.; Claver, C. Coord. Chem. Rev. 2004, 248, 2165.

(19) Gottschaldt, M.; Schubert, U. S. Chem.-Eur. J. 2009, 15, 1548.

(20) Storr, T.; Merkel, M.; Song-Zhao, G. X.; Scott, L. E.; Green, D. E.; Bowen, M. L.; Thompson, K. H.; Patrick, B. O.; Schugar, H. J.; Orvig, C. J. Am. Chem. Soc. 2007, 129, 7453.

(21) Wegner, R.; Gottschaldt, M.; Gorls, H.; Jager, E. G.; Klemm, D. Angew. Chem., Int. Ed. 2000, 39, 595.

(22) Bellot, F.; Hardre, R.; Pelosi, G.; Therisod, M.; Policar, C. Chem. Commun. 2005, 5414.

(23) Charron, G.; Bellot, F.; Cisnetti, F.; Pelosi, G.; Rebilly, J.-N.; Riviere, E.; Barra, A.-L.; Mallah, T.; Policar, C. Chem.-Eur. J. 2007, 13, 2774.

(24) Cisnetti, F.; Guillot, R.; Desmadril, M.; Pelosi, G.; Policar, C. Dalton Trans. 2007, 1473.

(25) Cisnetti, F.; Guillot, R.; Therisod, M.; Desmadril, M.; Policar, C. Inorg. Chem. 2008, 47, 2243.

(26) Cisnetti, F.; Marechal, J.-D.; Nicaise, M.; Guillot, R.; Desmadril, M.; Lambert, F.; Policar, C. Eur. J. Inorg. Chem. 2012, 3308.

(27) Damaj, Z.; Cisnetti, F.; Dupont, L.; Henon, E.; Policar, C.; Guillon, E. Dalton Trans. 2008, 3235.

(28) Garcia, L.; Franzoni, S.; Mussi, F.; Aumont-Nicaise, M.; Bertrand, H.; Desmadril, M.; Pelosi, G.; Buschini, A.; Policar, C. J. Inorg. Biochem. 2014, 135, 40.

(29) Garcia, L.; Lazzaretti, M.; Diguet, A.; Mussi, F.; Bisceglie, F.; Xie, J.; Pelosi, G.; Buschini, A.; Baigl, D.; Policar, C. New J. Chem. 2013, 37, 3030.

(30) Garcia, L.; Maisonneuve, S.; Marcu, J. O.-S.; Guillot, R.; Lambert, F.; Xie, J.; Policar, C. Inorg. Chem. 2011, 50, 11353.

(31) Garcia, L.; Maisonneuve, S.; Xie, J.; Guillot, R.; Dorlet, P.; Riviere, E.; Desmadril, M.; Lambert, F.; Policar, C. Inorg. Chem. 2010, 49, 7282.

(32) Neff, C.; Bellot, F.; Waern, J.-B.; Lambert, F.; Brandel, J.; Serratrice, G.; Gaboriau, F.; Policar, C. J. Inorg. Biochem. 2012, 112, 59.

(33) Contreras-Garcia, J.; Johnson, E. R.; Keinan, S.; Chaudret, R.; Piquemal, J. P.; Beratan, D. N.; Yang, W. T. J. Chem. Theory Comput.h 2011, 7, 625.

(34) Johnson, E. R.; Keinan, S.; Mori-Sanchez, P.; Contreras-Garcia, J.; Cohen, A. J.; Yang, W. J. Am. Chem. Soc. 2010, 132, 6498.

(35) Marshall, N. M.; Garner, D. K.; Wilson, T. D.; Gao, Y.-G.; Robinson, H.; Nilges, M. J. Nature 2009, 462, 113.

(36) New, S. Y.; Marshall, N. M.; Hor, T. S. A.; Xue, F.; Lu, Y. Chem. Commun. 2012, 48, 4217.

(37) Addison, A. W.; Rao, T. N.; Reedijk, J.; Vanrijn, J.; Verschoor, G. C. J. Chem. Soc., Dalton Trans. 1984, 1349.
(38) Martell, A. E.; Motekaitis, R. J. Determination and Use of Stability Constants; VCH: Weinheim, 1988.

(39) Hancock, R. D.; Martell, A. E. Comments Inorg. Chem. 1988, 6, 237.

(40) Comba, P. Coord. Chem. Rev. 1999, 182, 343.

(41) Bertini, I.; Gray, H. B.; Stiefel, E. I.; Valentine, J. S. In Biological Inorganic Chemistry, Structure and reactivity; University Science Book: Sausalito, CA, 2007.

(42) Martell, A. E.; Hancock, R. D.; Motekaitis, R. J. Coord. Chem. Rev. 1994, 133, 39.

(43) Haasnoot, C. A. G.; Deleeuw, F.; Altona, C. Tetrahedron 1980, 36, 2783.

(44) Gaussian 09, Revision D.01, Frisch, M. J.; Trucks, G. W.; Schlegel, H. B.; Scuseria, G. E.; Robb, M. A.; Cheeseman, J. R.; Scalmani, G.; Barone, V.; Mennucci, B.; Petersson, G. A.; Nakatsuji, H.; Caricato, M.; Li, X.; Hratchian, H. P.; Izmaylov, A. F.; Bloino, J.; Zheng, G.; Sonnenberg, J. L.; Hada, M.; Ehara, M.; Toyota, K.; Fukuda, R.; Hasegawa, J.; Ishida, M.; Nakajima, T.; Honda, Y.; Kitao, O.; Nakai, H.; Vreven, T.; Montgomery, J. A., Jr.; Peralta, J. E.; Ogliaro, F.; Bearpark, M.; Heyd, J. J.; Brothers, E.; Kudin, K. N.; Staroverov, V. N.; Kobayashi, R.; Normand, J.; Raghavachari, K.; Rendell, A.; Burant, J. C.; Iyengar, S. S.; Tomasi, J.; Cossi, M.; Rega, N.; Millam, M. J.; Klene, M.; Knox, J. E.; Cross, J. B.; Bakken, V.; Adamo, C.; Jaramillo, J.; Gomperts, R.; Stratmann, R. E.; Yazyev, O.; Austin, A. J.; Cammi, R.; Pomelli, C.; Ochterski, J. W.; Martin, R. L.; Morokuma, K.; Zakrzewski, V. G.; Voth, G. A.; Salvador, P.; Dannenberg, J. J.; Dapprich, S.; Daniels, A. D.; Farkas, Ö.; Foresman, J. B.; Ortiz, J. V.; Cioslowski, J.; Fox, D. J. Gaussian, Inc., Wallingford CT, 2009.

(45) Becke, A. D. J. Chem. Phys. 1993, 98, 5648.

(46) Lee, C. T.; Yang, W. T.; Parr, R. G. Phys. Rev. B 1988, 37, 785.

(47) Chaudret, R.; de Courcy, B.; Contreras-Garcia, J.; Gloaguen, E.; Zehnacker-Rentien, A.; Mons, M.; Piquemal, J. P. Phys. Chem. Phys. Chem. 2014, 16, 9876.

(48) de Courcy, B.; Pedersen, L. G.; Parisel, O.; Gresh, N.; Silvi, B.; Pilme, J.; Piquemal, J. P. J. Chem. Theory Comput. 2010, 6, 1048.

(49) Shannon, R. D. Acta Crystallogr., Sect. A 1976, 32, 751.

(50) Gillet, N.; Chaudret, R.; Contreras-García, J.; Yang, W.; Silvi, B.; Piquemal, J. P. J. Chem. Theory. Comput. 2012, 8, 3993.

(51) Abdel-Magid, A. F.; Mehrman, S. J. Org. Process Res. \& Dev. 2006, 10, 971.

(52) Hehre, W. J.; Stewart, R. F.; Pople, J. A. J. Chem. Phys. 1969, 51, 2657. 